\title{
The murder of Melaityappa and how Judge Mann succeeded in making 'the administration of justice palatable' to South Australian colonists in 1849
}

\author{
Skye Krichauff
}

On 17 September 1849, Henry Valette Jones and Henry Thomas Morris appeared at the Criminal Sittings of the Supreme Court charged with the wilful murder of Melaityappa, a Narungga man from Yorke Peninsula, South Australia. ${ }^{1}$ Described as 'pale, wasted and thoughtful', Jones and Morris were 'very different from the ruddy, reckless, dashing young fellows' who appeared at their Police Court trial three weeks earlier. ${ }^{2}$ Jones and Morris's incarceration and Supreme Court trial occurred during a crucial stage of Indigenous-settler relations in the 13-year-old colony's history. Disturbing news of outbreaks of violence and fatalities on Yorke and Eyre peninsulas had been reaching Adelaide since January 1849. ${ }^{3}$ For numerous reasons, the trial was unprecedented. It provided a unique opportunity to test the much-vaunted, consoling perception held by many South Australian colonists that, in their colony at least, Aboriginal people were protected and treated as equals under British law. Government officials, pastoralists and newspaper editors had strong and diverse opinions on who was to blame for settler-Aboriginal violence and how conflict could be avoided. The case bought to the fore the tension - or rather incompatibility

\footnotetext{
1 Morris was also referred to as Thomas Henry Morris and Harry Thomas Morris, Melaityappa as Melappa, Malappa, Malieappa, Mallartyappa and Kit.

2 South Australian Register [hereafter Register], 19 September 1849: 3C.

3 For a detailed account of violent encounters on Yorke Peninsula in 1849, see Krichauff 2011: 53-93. For Eyre Peninsula see Foster and Nettelbeck 2012: 84-85 and Foster et al. 2001: 47-49.
} 
- between humanitarian concerns for the 'natives' and the protection of colonists' interests (and the interests other citizens of Britain who lived in the British Isles or at various outposts of the British Empire).

Melaityappa's shooting is one of countless acts of violence committed by colonists against Aboriginal people. The work of scholars who conducted research in the 1980 s and 1990s indicated that across Australia (including Tasmania) approximately 20,000 Aboriginal people were killed by white violence, about 10 times the number of Europeans killed by Aboriginal people. ${ }^{4}$ Colonists were rarely tried for their crimes. In the Port Phillip District between 1841 and 1851, settlers were tried for the deaths of Aboriginal people on only two occasions. In both cases they were acquitted. ${ }^{5}$ Nor did settlers in New South Wales have much reason to fear conviction for crimes committed against Aboriginal people; during the first 25 years of British occupation, only four cases involving Indigenous-settler violence were tried and, of these cases, only one European (an escaped convict) was found guilty and hanged. ${ }^{6}$ The hanging of seven white men for the Myall Creek massacre in New South Wales in 1838 was exceptional and can be understood as a direct response to the findings of the House of Commons Report on the Select Committee of Aborigines published in 1837.7

In South Australia, between 1836 and the early 1860s, Europeans went to trial for murdering Aboriginal people on five occasions. Prior to Jones and Morris's trial, only ex-convict Thomas Donelly had been found guilty. ${ }^{8}$ In June 1849 , pastoralist James Brown was tried for the murder of a blind and infirm old man, three women, two teenage girls and three babies on Avenue Range (near Lucindale) in 1848.9 Brown was released on bail, enabling Advocate General William Smillie to procure more evidence before Brown's reappearance at the September Supreme Court criminal sittings.

Much scholarly work has been done documenting cases and investigating why British law failed to punish settlers for such violent acts. ${ }^{10}$ Detailed studies focus on specific difficulties government officials encountered when investigating crimes and the shortcomings of the British legal system. ${ }^{11}$ For example, despite there being no doubt of Brown's guilt in the minds of government officials, various factors prevented the Crown's successful prosecution. Brown's station was approximately 300 kilometres from Adelaide, the murders were not investigated until at least two

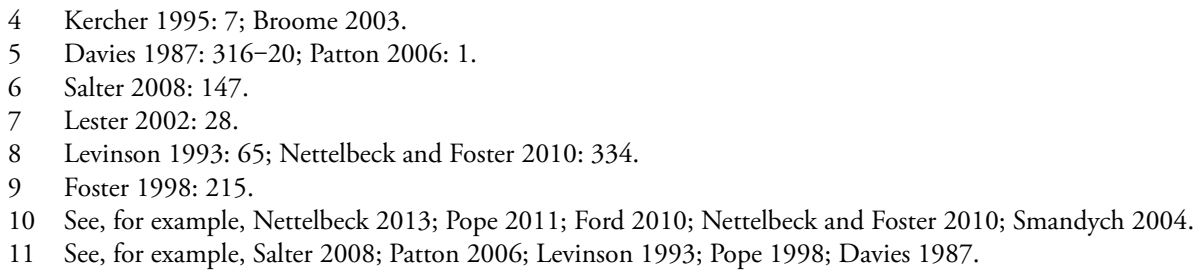


months had passed, Brown burnt the bodies and destroyed much of the evidence and no European testified against Brown. ${ }^{12}$ In their analysis of cases in which South Australian colonists were tried for crimes against Aboriginal people, Amanda Nettelbeck and Robert Foster additionally draw attention to the prejudice and self-interest of frontier officials (who were subject to the same culture of solidarity that influenced other officials), the ambiguities of 'self-defence' (a cliché utilised by settlers to justify firing on Aboriginal people), the cover-up and denial inherent in coronial inquests, and difficulties surrounding the admissibility of Aboriginal evidence in courts of law. ${ }^{13}$ They note that authorities who sincerely attempted to bring settlers' violent acts out of obscurity were not necessarily 'willing or even able to prosecute those acts with "exemplary severity". ${ }^{14}$

Alan Pope, Nettelbeck and Foster directly refer to Jones and Morris's case to validate their broader observations. They draw on the unusual circumstances by which Melaityappa's shooting came to the attention of government officials to demonstrate settler secrecy and solidarity, and they refer to the Supreme Court trial to illustrate the failure of Aboriginal evidence to convict settlers. ${ }^{15}$ However, Jones and Morris's case was an anomaly. As such, it serves as an excellent means through which to illustrate other, less obvious factors that prevented legal justice for Aboriginal people. With the exception of the lack of credibility given to Aboriginal evidence, the mechanisms Nettelbeck and Foster identify (outlined in the previous paragraph) by which settler crimes could be ignored, dismissed or fail to lead to a conviction were not applicable. An exhaustive and contextualised analysis of documents relating to the case combined with knowledge of the biographies of key players provides additional nuance to previous scholarly findings and draws to light some incremental (perhaps more insidious) reasons why British law consistently failed Aboriginal people.

Broad comparative studies inevitably conclude with the observation that British law worked to protect settler interests and establish settler sovereignty. For example, Nettelbeck notes that magistrates had no formal training and, with jurors, were comprised of members of the landed classes whose interests they inadvertently represented. Those who served the economic development of the colony were unlikely to receive a guilty verdict and the law was securely bound to the maintenance and protection of settler sovereignty. ${ }^{16}$ Barry Patton argues that although 'colonial law was not uniformly and monolithically contrary to the protection of Aboriginal people and their interests ... at each procedural stage, simple prejudice or systematic partiality operated'. ${ }^{17}$ Lisa Ford points out that settler violence was 'clothed in law',

12 Foster 1998: 215.

13 Nettelbeck and Foster 2010: 324-33.

14 Nettelbeck and Foster 2010: 327.

15 Pope 2011: 50; Nettelbeck and Foster 2010: 332.

16 Nettelbeck 2013: 378-79, 388.

17 Patton 2006: 10. 
which, in important ways, settlers constituted and controlled; 'authority itself was enmeshed in and compromised by settler violence' and frontier settlers were 'seldom merely lawless' but 'savvy masters of the discourses and the politics of settler jurisdiction'. ${ }^{18}$ This microstudy provides further evidence for these valid conclusions and, in addition, demonstrates the extent of procedural prejudice and partiality.

By using phrases such as 'settler solidarity' and 'settler secrecy', scholars who investigate the failure of the British colonial judicial system to protect Aboriginal people imply settlers were a homogenous and relatively unified group. However, astute observations made in 1849 cut straight to the heart of the 'problem' of settlerAboriginal violence and starkly remind current generations that the fundamental hypocrisy and unethicalness of British colonisation was understood by some colonists at the very time Aboriginal land was being occupied. Letters and editorials that appeared in newspapers during Jones and Morris's incarceration in gaol and government correspondence following the verdict demonstrate that neither settler violence nor the biased judicial system were ubiquitously condoned. A recognition of distinctions between and connections among settlers, the multiplicity of settler positions and the varying degrees and extents to which different groups used, constituted and controlled the law enables a deeper understanding of why British law failed to provide justice for Aboriginal people.

\section{Setting the scene, 1849}

Melaityappa was shot in August 1849, approximately two years after Narungga country was occupied by pastoralists. An awareness of the reporting of previous Aboriginal-European confrontations on Yorke Peninsula (and other districts) in Adelaide newspapers throughout 1849 provides useful context for understanding South Australian colonists' sentiments regarding both settler-Aboriginal violence and Jones and Morris's trial.

On 20 January, overseer George Penton shot an Aboriginal man defending nine sheep carcasses, part of a flock of sheep that had been taken from pastoralists Anstey and Giles. ${ }^{19}$ Penton notified the police and this death was reported in the Adelaide Times on 5 February. ${ }^{20}$ No concern was shown for the murdered man; to the contrary, Penton's decisiveness and honesty were praised. Neither the police nor Protector of Aborigines, Matthew Moorhouse, were sent to investigate. On 3 July, a party of five settlers, which included Penton and George Field (who was later charged), surprised and fired upon a group at Hardwicke Bay. A man, Nantariltarra, was shot through

18 Ford 2010: 107, 85.

19 Observer 5 May 1849: 3; Adelaide Times 5 February 1849: 2D; Observer 22 October 1887: 41. See Krichauff 2011: 63 .

20 Adelaide Times, 5 February 1849: 3B. 
the head and the Europeans watched as a child drowned. ${ }^{21}$ Although reported to the police, these deaths were not reported in the newspapers. Again, neither police nor the Protector were dispatched. Contrastingly, when Narungga man Tulta speared a shepherd named Armstrong on 11 July, three days later the Register reported:

The aborigines on Yorke's Peninsula are becoming more troublesome than heretofore. A shepherd named Armstrong has been killed by a spear, and from the flocks of Mr Anstey no less than 200 sheep were recently abstracted by the wily blacks. ${ }^{22}$

Colonial officials reacted speedily to the white man's death. On 15 July, Acting Corporal McCulloch and two constables were dispatched to the peninsula. ${ }^{23}$ While they were on the peninsula, Tulta and Wilcooramalap murdered Scott, a shepherd who was present at Nantariltarra's murder. McCulloch arrested Wilcooramalap and arrived in Adelaide on 11 August. By 13 August, this payback killing and the subsequent court case began receiving press coverage. ${ }^{24}$

\section{Accidental 'discovery' of Melaityappa's shooting?}

Tellingly, the same day news of Scott's murder reached Adelaide, Moorhouse was instructed to investigate. ${ }^{25}$ Moorhouse arrived on Yorke Peninsula on 19 August 1849 accompanied by McCulloch, a mounted policeman and three Aboriginal men (one of whom was interpreter Jim Crack). On 22 August, the party 'came upon' an encampment of Narungga, which included Melaityappa who 'was suffering dreadfully from three ball wounds he had received about 10 days before'. ${ }^{26}$ Pope, Nettelbeck and Foster draw attention to the accidental or coincidental means by which this case was brought to Moorhouse's attention. ${ }^{27}$ To the contrary, I suggest it was no coincidence that Moorhouse and McCulloch became aware of Melaityappa's shooting.

Historical records reveal intriguing and enlightening connections between Moorhouse, McCulloch and Jim Crack. McCulloch was involved in the earlier arrests of both the ex-convict Thomas Donelly and squatter James Brown for their murders of Aboriginal people. ${ }^{28}$ Jim Crack had spent several years at the Native School in Adelaide (where Moorhouse got to know him) and had been living on Yorke Peninsula since early $1849 .{ }^{29} \mathrm{Jim}$ Crack had recently accompanied McCulloch

\footnotetext{
21 See Register, 5 September 1849: 4AB; 19 September 1849: 3CDE.

22 Register, 14 July 1849: 3E.

23 Government Record Group [hereafter GRG] 24/6/1849/1527, State Records of South Australia [hereafter SRSA].

24 Adelaide Times, 13 August 1849: 3G; Register, 15 August 1849: 2B.

25 GRG 24/6/1849/Moorhouse's quarterly report, 23 October 1849, 19071/2, SRSA.

26 Register, 8 September 1849: 4A.

27 Pope 2011: 153; Nettelbeck and Foster 2010: 332.

28 Levinson 1993: 56.

29 Judge Cooper's notes, September 1849, Supreme Court Note Books, NNB 27 (the letter is in a box of unnumbered incoming correspondence for 1849); Adelaide Times, 3 September 1849: 4D. See also Krichauff 2015: 15 .
} 
on his tour of Yorke Peninsula and assisted during McCulloch's investigation of Scott's murder. ${ }^{30} \mathrm{~A}$ close reading of the available records, which is alert to the presence and motivations of Aboriginal people, enables the significant roles played by Aboriginal people to be acknowledged. I argue Jim Crack and his Aboriginal companions deliberately led Moorhouse and McCulloch to Melaityappa and that Jim Crack played a key role in bringing Jones and Morris to trial. ${ }^{31}$

Melaityappa told Moorhouse (through Jim Crack) that he had been shot by 'two gentlemen on horseback, one having a double barrelled gun, and the other a single barrelled one'. ${ }^{32}$ Moorhouse cut the ball from Melaityappa's arm and travelled with Melaityappa and Perria ${ }^{33}$ (a 10-year-old boy who witnessed the shooting) to George Milner Stephen's head station where Jones was identified and apprehended. ${ }^{34}$ After the group arrived in Adelaide on 28 August, Morris was apprehended, taken to the Aborigines' location and picked out of an identity parade by Melaityappa and Perria. ${ }^{35}$

\section{The reporting of settler-Aboriginal conflict}

In his analysis of colonial newspapers in New South Wales, South Africa and New Zealand, Alan Lester pertinently points out that colonial newspapers 'founded by settlers to represent and further their interests' were influential not only in reflecting but also constructing a colonial identity. ${ }^{36}$ Lester focuses his examination on papers aimed at free, propertied and respectable settlers (Adelaide newspapers fit that mould) and demonstrates how the settler press provided an anti-humanitarian discourse in response to the powerful humanitarian critique of colonialism that emanated from London in the 1830s-1840s. According to Lester, the settler press attacked humanitarian officials' partiality and settlers campaigned against 'the humanitarian complex as a whole'. 37

If European aggressions on Yorke Peninsula were reported in Adelaide newspapers, they were downplayed while the 'deeply provocative' acts of 'the blacks' were emphasised. Similarly, the murders of colonists James Beevor and Mrs Easton on Eyre Peninsula in May 1849 were widely reported while the (earlier) poisoning of at least five Aboriginal people in the same district by shepherd Patrick Dwyer was not brought to the public's attention until months later. Because the Adelaide

\footnotetext{
30 See Krichauff 2011: 78.

31 For further evidence to support this argument, see Krichauff 2011: 113-18.

32 Register, 8 September 1849: 4A.

33 Also referred to as Birria, Birris, Piaria.

34 Register, 1 September 1849: 4D; GRG 24/6/1849/19071/2, SRSA.

35 Adelaide Times, 3 September 1849: 4D.

36 Lester 2002: 30-33.

37 Lester 2002: 30-33.
} 
public was largely dependent upon local newspapers for information about remote districts, the lack of reporting of settlers' crimes against Aboriginal people had serious consequences and requires recognition when analysing colonists' reactions to Melaityappa's shooting.

Since January 1849, Adelaide residents had been receiving news of the deaths of several settlers at the hands of Aboriginal people. Articles and letters referring to the natives' 'treachery' and 'brutality' and the need to 'teach the blacks a lesson' had been appearing in Adelaide newspapers. Skewed reporting can be blamed on the distance from Adelaide, the absence of government officials in remote districts, cross-cultural miscommunication, the culture of solidarity and secrecy that existed amongst pastoralists and their employees, and newspaper editors' and government officials' uncritical acceptance and repetition of one group of people's (i.e. frontier settlers') version of events. However, news of Melaityappa's shooting disrupted this outraged discourse and suggests a need to look for additional reasons for skewed reporting. An awareness of the speed and tenor of the reporting of Melaityappa's wounding illustrates that the moderate and delayed reporting of settler crimes is, arguably, a reflection of the news received as much as a sign of the prejudices of editors - regarding remote districts, newspaper editors were themselves dependent on information received. A lack of reports of European aggressions meant editors' (and, ultimately, the public's) perception of settler innocence may have been genuine.

Articles and editorials that appear in the Adelaide press concerning Melaityappa's shooting complicate Lester's binary between humanitarians (located in Britain) and anti-humanitarian settlers (located in the colonies) and the related tendency of some scholars to generalise and homogenise 'settler' sentiments and actions. The initial reaction of newspaper editors and government officials to Jones and Morris's crime appears to be one of genuine disapproval and condemnation. On 1 September, one editor called offences by white people against natives 'appalling', and stated that the charge of murder 'deserves the most searching enquiry' as 'inoffensive natives are not to be shot down like wild-dogs with impunity'; 'humanity and justice alike demand that if we force these poor people from their haunts and accustomed food, we should at least protect them from further or more desperate violence'. ${ }^{38}$ On 5 September, the Register published an editorial titled 'Murderous Encounters':

Those settlers who are confirmed in the pastoral career have almost insensibly acquired the persuasion of some 'right divine' by virtue of which the lands included in their 'runs' and the aboriginal occupiers of the soil have become wholly subject to their absolute rule. They view the sable denizens of the forest as dangerous interlopers, or something worse. ${ }^{39}$

38 South Australian Gazette and Mining Journal [hereafter SAGM], 1 September 1849: 2E.

39 Register, 5 September 1849: 2E. 
Some Adelaide editors perceived themselves as representatives of liberal-thinking, humanitarian colonists; in South Australia, settlers who owned and controlled the press were not necessarily anti-humanitarian.

\section{Police Court trial}

On 29 August 1849, the Colonial Surgeon operated on Melaityappa and Morris and Jones appeared at the Police Court. Perria, Moorhouse and McCulloch gave damning evidence. Perria had seen Jones and Morris ride up to Melaityappa on small grey horses and shoot Melaityappa in the arm, foot and body; they then rode off, taking with them two nets and two waddies, which were later recovered. When McCulloch visited the site of the shooting, he saw the tracks of two small horses, which corresponded with the tracks of the grey horse Jones was riding when identified by Melaityappa. The marks of the ball taken out of Melaityappa's arm matched those produced by a double-barrelled rifle in Morris's possession. Bail was refused, which 'surprised' Jones and Morris's employer George Milner Stephen, who also doubled as their defence lawyer. Despite receiving 'all the assistance that medical talent could devise', Melaityappa died on 30 August. ${ }^{40}$ After the Colonial Surgeon gave further damning evidence at the Coronial Inquiry, Jones and Morris were charged with wilful murder. ${ }^{41}$

Jones and Morris's upcoming trial caused a stir in colonial society. Naïve city dwellers had their illusions of peaceful occupation shattered while experienced frontiersmen's understandings of legal sanctity were unsettled. Unlike James Brown's case (which had not been dismissed but was also to be heard in the September Criminal Sittings), the material, circumstantial and testimonial evidence against Jones and Morris was seemingly irrefutable. The Protector, Sergeant Major McCulloch and Colonial Surgeon were personally involved and appeared as witnesses. Their social position and 'respectability' meant their testimonies could not be readily dismissed. Doubly painful for the Adelaide public was the awareness that Jones and Morris were supposedly 'gentlemen' who should 'show an example of conduct worthy of their position'. ${ }^{42}$ Morris was the nephew of ex-Governor Hindmarsh. Morris's employer and legal representative, George Milner Stephen, was married to Morris's cousin (Hindmarsh's daughter).

Any convenient perception that immoral acts committed on Aboriginal people were perpetrated by uneducated men belonging to the lower classes could no longer be sustained. A sense of many colonists' disbelief and denial is glimpsed through the Register's need to point out that the Police Court jury that found Jones and Morris

40 Adelaide Times, 3 September 1849: 3G.

41 Register, 1 September 1849: 3C.

42 Register, 19 September 1849: 3D. 
guilty was 'a most respectable one'. ${ }^{43}$ The duty of prosecuting Jones and Morris was understood by Judge Mann as 'painful' and 'unpleasant'. ${ }^{44}$ Morris faced an additional charge of assaulting two Aboriginal women. Interestingly, it seems that men who physically assaulted women were judged more harshly by the public than men who killed Aboriginal people; Stephen requested that Morris be committed for the murder charge because the assault charge 'was, in fact, prejudicing the public mind against him'. ${ }^{45}$

\section{Laying the blame}

Publicity surrounding the trial meant government officials, newspaper editors and the general public could not bury their heads in the sand or disguise with euphemisms Aboriginal fatalities occurring at the frontiers of British settlement. The trial's unprecedentedness, the important questions it raised and the farreaching implications of the impending outcome inspired frank, honest and radical reflections regarding the causes of Aboriginal-settler violence. Colonists wanted someone to blame, some way to deflect attention from the real causes of crosscultural violence. Aboriginal people were an easy target. Having outlined how he had 'suffered from Native aggressions', William Newnham of Gawler Town concluded 'the conviction of a white man, under circumstances such as those experienced by the settlers on Yorke's Peninsula, would be nothing short of murder' ${ }^{46}$ Colonist 'WH' suggested that, during the years of Moorhouse's official appointment, the Protector 'might easily' have 'made himself a master of the dialects of these rude tribes'. ${ }^{47}$ (This unrealistic expectation displays an ignorance of the distinct and diverse languages and dialects of South Australia's numerous Aboriginal groups.) Having stated 'the best and only means of teaching refractory aborigines the sacred nature of ... British jurisprudence, is to give them a severe lesson ... a little cold lead, well applied', a colonist using the pseudonym 'Blue Nose' perceived 'the government and the Protectorship' to be 'virtually responsible for any undue cruelties towards the natives from the perfect indifference hitherto shown to the most earnest entreaties of the whites for protection'. ${ }^{48}$ But Moorhouse had strongly recommended the establishment of a police force on Yorke Peninsula as early as January 1848, and he was compelled to wait for instructions from the government before investigating any 'affrays'.

43 Register, 1 September 1849: 3C.

44 Register, 12 September 1849: 3CD; 19 September 1849: 4A.

45 Register, 5 September 1849: 4A.

46 Adelaide Times, 17 September 1849: 3G.

47 Register, 19 September 1849: 2C.

48 Register, 8 September 1849: 4A. 
The Register's editors declared 'the Christians' the 'real invaders':

[although Christians] may be too humane to tolerate the idea of the wholesale extermination or the 'singling out' of the 'black vermin', as they are called, they nevertheless are of the opinion that a system of slavery should be introduced whereby the blacks might be subjected to a lengthy term of coercion, and thus rendered serviceable to the whites and partially civilized. ${ }^{49}$

The editors are referring to the pending establishment of a 'Native Training Institution', where Aboriginal people would be educated in European habits, religion and occupations. Key advocates and supporters for the institution were Anglican Archbishop Short and Archdeacon Hale who, since 1848, had been openly critical of the natives' condition and the ineffectiveness of efforts to 'Christianise' them. ${ }^{50}$

The Register's editors also blamed the government - despite receiving (indirectly) revenue of at least $£ 750$ from Yorke Peninsula colonists, 'all the government has done is [send] three or four of the mounted police to scour the country and make some abortive attempts to restore peace'. Now Yorke Peninsula 'has become a largely productive portion of South Australia', the government should 'bestir itself' and spend at least $£ 1,000$ per year on 'its protection and local control'. ${ }^{51}$

\section{Settler diversity}

South Australian colonists' perceptions, sentiments and actions towards Aboriginal people and their treatment varied. Broadly speaking, there were differences between humanitarian government officials who attempted to follow orders from London's Colonial Office, between frontier settlers and those who remained in Adelaide, between squatters-cum-pastoralists who leased vast tracts of land and farmers who purchased 640-acre blocks, between pastoral employers and their employees. These lines were not distinct but overlapped and blurred - government officials were settlers, Adelaide residents were pastoralists. In addition, there were differences between members of each group, which depended upon individual motives, histories, experiences and personalities.

\section{The position of Moorhouse and certain government officials}

Moorhouse's personal involvement in Melaityappa's case appears to have sparked his ire and made him unusually forthright in publicly and privately voicing his empathy for Aboriginal people. In the first of two letters published in the Register during Jones and Morris's incarceration in gaol, Moorhouse stated 'it is to be hoped that those

49 Register, 5 September 1849: 2E, original emphasis.

50 Brock and Kartinyeri 1989.

51 Register, 5 September 1849: 2E. 
who may be made murderers by their own masters will not be treadmilled on the revolver for self-defence, ${ }^{52}$ thus vocalising his awareness and frustration regarding the inadequacies - or hypocrisy - of British law and the reality of the pastoral chain of command. Ten days later, he bluntly stated:

The blacks were here before us ... At length the white man came, and the power of civilisation has continued to monopolise and fence in the soil, and to shut out and drive away the game, and occasionally to shoot down the native tribes. All vice reacts on its perpetrators, and it is evident there is still such a thing as 'the cry of blood'. ${ }^{53}$

When Aboriginal people committed crimes, they were 'revenging invasion, rapacity, and adultery'; they 'are entitled to the sympathy of every man who would boast a generous humanity'. Moorhouse accused the settlers of being 'blind' to 'their own permanent interests' and boldly stated that although the 'development of agriculture, mining, trade and commerce' was generally understood as necessary for the advancement and prosperity of the colony ('provincial locomotion'), 'the blacks and whites, here, are antagonistic'. ${ }^{54}$ In these public statements, Moorhouse cut straight to cause of settler-Aboriginal conflict.

He was not alone in seeking justice for Aboriginal people. Moorhouse and McCulloch promptly and decisively attended to Melaityappa before tracking and arresting Jones and Morris. Both gave clear, damning evidence against Morris and Jones and were supported by other men in high office. Police Commissioner Tolmer fully reported the charge against Jones and Morris, which he described as 'one of the most serious kind'. ${ }^{5}$ The Advocate General was thorough and determined throughout his prosecution. ${ }^{56}$

\section{Pastoralists}

Wealthy colonists invested in the pastoral industry as a means of making a quick fortune. Many (such as Jones and Morris's employer) resided in Adelaide while leaving the dirty work of occupying Aboriginal land to their overseers, managers, shepherds and hut-keepers. There is no doubt the majority of early pastoralists were aware of and took a pragmatic and mercenary approach with regard to the means by which Aboriginal land was occupied. Penton's employer, for example, attempted to 'conceal' the murder of his shepherd Scott in order 'that the shepherds might not be deterred from going out with their sheep' ${ }^{57}$ Overseers were the pastoralists' henchmen; they were chosen and instructed according to their employers' values

\footnotetext{
Register, 29 August 1849: 3B.

Register, 8 September 1849: 4B.

Register, 8 September 1849: 4B, original emphasis.

GRG 24/6/1849/18831/2, SRSA.

Register, 19 September 1849: 4A.

Register, 19 September 1849: 3F; GRG 35/1849, SRSA.
} 
and priorities. Following the murders of shepherds Armstrong and Scott (in July and August 1849 respectively as referred to above), overseers Penton and Morris armed their subordinates with guns, scoured their runs and forced shepherds to go out with their flocks. By such means pastoral employees were indeed 'made murderers by their masters'.

As members of Adelaide's social elite, pastoralists were used to being heard by those in the highest echelons of colonial authority. However, due to the unprecedented circumstances by which Jones and Morris's crime was brought to several highly placed officials' attention and the weight of circumstantial and material evidence against Jones and Morris, the pastoralists could not be certain of the trial's outcome. Aware a guilty verdict would have numerous negative repercussions for their economic enterprises, pastoralists resorted to desperate methods. On 1 September, Stephen wrote to the Governor on behalf of 'the Settlers on Yorke's Peninsula' 'to request the favor of His Excellency's granting them an interview on the subject of the aggression of the Aborigines'. ${ }^{58}$ Confident of securing a meeting, Stephen expressed his willingness to communicate the appointed time to the settlers. However, the Governor snubbed the pastoralists by coldly responding that any future 'communication should be had with me in writing'. ${ }^{59}$ A sense of the pastoralists' irritation can be gleaned through Blue Nose's complaint that 'the most earnest entreaties of the whites for protection ... thundered against the stone walls of government house, instead of the ears of its somnolent inmates'. ${ }^{60}$

Another cause of pastoralists' anxiety was Judge Cooper's illness. The position of Acting Judge would ordinarily go to the Advocate General who, at the time, was William Smillie whom the Adelaide Times described as having 'partialities and dislikes and other indications of littleness of mind'. ${ }^{61}$ According to the Adelaide Times in the days leading up to Jones and Morris's trial, 'the colonists would have no confidence whatever' in Smillie's appointment; any attempt to carry it out would 'be met with an unmistakeable demonstration of public disapprobation'. ${ }^{62}$ For reasons that were soon to become apparent, Charles Mann was the colonists' preferred choice.

\section{The wider public}

It is difficult to know what proportion of the settler population sympathised with Melaityappa (and Aboriginal people in general) and what proportion sympathised with Jones and Morris (and pastoralists and their employees). But the researcher gets a sense that the majority of the population refused to acknowledge European

58 GRG 24/6/1849/1634, SRSA.

59 GRG 24/6/1849/1634, SRSA.

60 Register, 8 September 1849: 4A.

61 Adelaide Times, 10 September 1849: 3G.

62 Adelaide Times, 3 September 1849: 2G. 
determinants of Aboriginal-settler violence. Moorhouse found in his intercourse with society that the doctrine now broached is, "shoot them down". ${ }^{63}$ When Jones and Morris appeared at their Supreme Court trial, 'the court became crowded ... An expression of commiseration for the prisoners and anxiety for the result was visible on every face' ${ }^{64}$ For settlers involved in the pastoral industry, the incarceration, trial and determined pursuit of Jones and Morris was a shock. These preliminary invaders of Aboriginal land understood cross-cultural clashes as an inevitable consequence of colonialism and perceived the government's punishment of settlers for crimes inherent and integral to the work of 'taking up' 'new' land as unfair and hypocritical. William Newnham criticised those 'who have not gone far beyond the precincts of the city, or the efficient protection of the more populated districts, and who know nothing of the fearful risks at which the distant settlers have cleared their way'. Such people 'have a philanthropy founded on error, and maintained in ignorance'. ${ }^{65}$

A sense of the outrage and perhaps desperation that Jones and Morris's prosecution triggered in some can be gleaned through Blue Nose's scathing reference to 'the Protectorship' that 'has ferreted out numberless pseudo murders and other barbarities perpetrated against the natives'. ${ }^{66}$ Blue Nose depicted McCulloch as 'a listless policeman who snuffs no promotion from the conviction of a black-skin, but who is quickly transformed into the wily maker-up of a "case" the moment that Government urges him to "investigate" any alleged delinquency on the part of the whites' ${ }^{67}$ The Advocate General and others were labelled 'a horde of distinctionseekers' who 'come into court with exceedingly bad grace to prosecute the whites for no virtual offence' ${ }^{68}$

\section{The potential for events to unfold differently}

From the time Jones and Morris were incarcerated in the Adelaide Gaol until their Supreme Court trial (from 28 August to 17 September 1849), the potential existed to set the course of Aboriginal-settler relations on a new path. During these weeks, the opportunity existed to openly acknowledge the antagonism between settler and Aboriginal interests, debate the hypocrisy of 'Christian' goals for the Aboriginal population's 'civilisation' and 'improvement', break the power and influence of the pastoralists, demonstrate that the lives of Aboriginal people were of greater concern than the short-term economic profits of a few and put in place policies that genuinely recognised and attempted to ameliorate the injustices suffered by

63 Register, 29 August 1849: 3B.

64 Register, 19 September 1849: 3C.

65 Adelaide Times, 17 September 1849: 3G.

66 Register, 8 September 1849: 4AB.

67 Register, 8 September 1849: 4AB.

68 Register, 8 September 1849: 4AB. 
Aboriginal people. Newspapers raised the possibility of settlers abandoning some districts on the Yorke and Eyre peninsulas. The Register's editors suggested if 'the protection of the aborigines is to be anything more than a mockery ... the whole of the pastoral regulations should undergo wise and liberal revision' ${ }^{69}$ Moorhouse called for a public meeting to openly discuss 'the subject' of 'the Aborigines'..$^{70}$

Punishing Jones and Morris in accordance with their crime would send a powerful message. A close look at newspaper articles and correspondence between the Governor and various officials during Jones and Morris's incarceration and after their trial illustrates who in actuality controlled and constituted the law. The Governor appointed the Acting Judge on the advice of the Legislative Council, which was comprised of four government officials and four colonists. With the exception of the Governor, all members of the Legislative Council were landholders. On 5 September, the Register 'relieve[d] the public anxiety with respect to the appointment of a second judge, that appointment falling on Judge Mann'; 'indeed, the Executive could scarcely have determined otherwise, the voices of the people being unanimous in favour of the eligibility of that learned Gentleman. ${ }^{71}$ The Adelaide Times stated 'we accept this appointment as a concession to the just and reasonable wishes of the colonists' as judges must 'be free from partialities and dislikes and other indications of littleness of mind ... to make the administration of justice palatable. ${ }^{72}$ Perhaps Advocate General Smillie's unrelenting pursuit of James Brown demonstrated his 'partialities and dislikes'.

\section{Supreme Court trial}

If the Advocate General's partialities and dislikes were unpalatable to many colonists, Judge Mann's were much more appetising. In opening the Supreme Court Criminal Sittings on 10 September, Mann (referring to settler-Aboriginal violence) 'regretfully' observed the 'numerical increase' in crimes of 'a more fearful nature' and stated that 'happily for the province' such crimes 'have hitherto been of rare occurrence' ${ }^{73}$ Mann conveniently perceived the rarity of trials relating to Aboriginal-settler violence as evidence such violence rarely occurred. Mann provided further reassurance to those sympathetic to Jones and Morris by immediately dismissing the case against Brown and by having a dig at the Advocate General (who was responsible for pursuing the case) by stating 'the case was scarcely such as to require [Mann] to enter into any lengthened detail'. Introducing the case against the Aboriginal murderers of Beevor and Easton, Mann said these 'are cases the atrocious cruelty of which is aggravated

69 Register, 5 September 1849: 2E, original emphasis.

70 Register, 29 August 1849: 3B.

71 Register, 5 September 1849: 3A.

72 Adelaide Times, 10 September 1849: 3G.

73 Register, 12 September 1849: 3CD. 
by the undeviating kindness which the natives had uniformly received at the hands of their victims'. Mann then reminded the jury they ought not 'allow feeling of any kind to influence' their decision before remarking 'a more kindhearted and gentlemanly man' than Mr Beevor 'never existed'. Referring to Europeans facing charges, Mann did not overlook the circumstances connected with 'attacks on the blacks' who appear, in many instances, 'to have been the original aggressors'. ${ }^{74}$

Although pastoralists could begin to breathe more easily, there was no guarantee at this stage of Jones and Morris's acquittal, with Mann stating:

the admissions of [Jones and Morris] in the presence of their connection subject to his decease, with property that is identified as having been in his possession previous to his death, and various other similar circumstances, so strongly corroborate the testimony of the native witnesses, that your duty, however unpleasant, is, it seems to me, clear. $^{75}$

However, over the next three days, the likelihood of Jones and Morris's conviction dramatically reduced. Although the scant records allow only a speculative interpretation of events, they are nevertheless enlightening.

Successive amendments to the Aborigines Evidence Act (in 1844, 1846 and 1848) increasingly enabled previously unadmissable Aboriginal evidence to be heard in court. By 1848, unsworn evidence was admitted, evidence could be presented as written statements, and unsworn interpreted evidence accepted. ${ }^{76}$ On 13 September 1849, Mann interviewed Perria, Jim Crack and Moorhouse to hear Perria's evidence and determine Jim Crack's suitability as an interpreter. Jim Crack could not count beyond the number 10 and had forgotten the difference between a week and a month. ${ }^{77}$ Mann informed the Advocate General that Jim Crack could not be relied on as a 'competent interpreter. ${ }^{78}$ The Advocate General replied by reminding Mann that the case did not rely on native evidence for dates or numbers and 'they were bound to receive as much of the truth as the witness could impart' - although unable to tell the time or the date, natives 'could describe an occurrence and identify and individual'. ${ }^{79}$

To date, only an ex-convict had been found guilty for the murder of an Aboriginal man. The sacrifice of Jones's and Morris's lives to maintain the status quo and perpetuate the illusion of the law's effectiveness and impartiality was, however, more problematic. To hang the nephew of an ex-Governor would raise serious questions

\footnotetext{
74 Register, 12 September 1849: 3CD.

75 SAGMJ, 13 September 1849: 3D.

76 Pope 2011: 48-49.

77 Judge Cooper's notebook beginning 'Civil Sittings August 31st 1848', NNB 27. This notebook has recently been transferred from the archives of the Supreme Court to SRSA where it has been listed as GRS 13038/1/P/Vol. 6 .

78 Register, 15 September 1849: 3C.

79 Register, 15 September 1849: 3C.
} 
and draw unwanted attention - both in the antipodes and in Britain - to the means by which the British Empire was created and maintained. It would send a strong message to British citizens and colonists that economic self-interests did not override the rights of Aboriginal people and would, initially at least, hinder the economic prosperity of the colony. How was Mann - acting as the highest placed judge in South Australia at the time - to resolve this conundrum whilst keeping face regarding the superiority and impartiality of British law?

Legislation passed by the Legislative Council as recently as July 1849 made judges (or Justices of the Peace) responsible for assessing the weight and credibility of unsworn Aboriginal evidence (and meant that finally settlers could be convicted solely on the uncorroborated testimony of an Aboriginal person) ${ }^{80}$ However, Mann cannily chose to involve the Grand Jury in the assessment of Jim Crack's suitability as an interpreter and Perria's reliability as a witness. ${ }^{81}$

Although it is uncertain exactly what discussions took place between Mann and the Grand Jury between 13 and 15 September, several clues survive. In a written report dated 19 October 1849 addressed to the Governor, Mann stated:

The answers of Jim Crack satisfied me that in cases similar to that ... against Messrs. Morris and Jones ... the testimony of a native by a native interpreter might be depended upon. Through the medium of the Interpreter I examined and admonished the native boy and I found that the answers of the witness were clear and distinct. Before the Grand Jury no difficulty was experienced. ${ }^{82}$

Mann's statement contrasts starkly with a report that appeared in the Register on 15 September; having examined Jim Crack and Perria on 14 September, the Grand Jury found 'numerous and important' 'contradictions between the statements of the native witnesses'. Consequently, 'the Grand Jury have almost unanimously expressed their regret at finding a true bill' against Jones and Morris. ${ }^{83}$ However, because the trial was already fixed, its 'consummation [was] unavoidable ${ }^{84}$ - it seems Jones and Morris's trial on Monday 17 September was a farce.

Like the Legislative Council, the Grand Jury was primarily made up of landholders. ${ }^{85}$ As such, they held 'prejudices that favored the interests of the recognised landholders ${ }^{86}$ and were 'potentially subject to the same culture of solidarity that influenced other settlers' ${ }^{87}$ Later, on 8 October 1849, Moorhouse informed the Governor that

80 Register, 15 September 1849: 3C.

81 Observer, 15 September 1849, 3C.

82 Mann to Colonial Secretary, 19 October 1849, GRG 24/6/1849/1908, SRSA, emphasis added.

83 Register, 15 September 1849: 3E.

84 Register, 15 September 1849: 3E.

85 See Register, 12 September 1849: 3C.

86 Patton 2006: 3.

87 Nettelbeck and Foster 2010: 325. 
'only two of the Grand Jury possessed favourable feelings towards [the Natives]'. ${ }^{88}$ By including the Grand Jury in the process of assessing Jim Crack's and Perria's suitability, Mann effectively handballed the responsibility for the outcome of the case to those with vested interests.

The Grand Jury had one more trump card to play. Midway through Jones and Morris's trial on 17 September they came into court and interrupted proceedings. The Foreman, John Hallett - a pastoralist who leased vast tracts of land in the mid-north of South Australia and who had himself been implicated in 1844-45 in covering up his overseer's murder of two Ngadjuri people ${ }^{89}$ - read aloud from a document presented to Mann. Having 'bestowed their most careful and minute investigation to the cases bought before them' the Grand Jury found 'the examination of the Aborigines' was 'attended with the difficulties which your Honour in your charge anticipated and suggested'. Hallett then laid some blame on the colonial government by stating that the districts in which Europeans murdered Aboriginal people were not under sufficient police control or the protection of an officer whose duty it was to 'protect the savage, and to guard the settlers'. ${ }^{90}$

The trial continued. Mann stated Jim Crack could 'translate matters of fact not involving time or numbers'. ${ }^{11}$ The defence retorted that, as the 'whole essence of the case depended on the exact date of occurrence', Jim Crack was not competent and the case should be dismissed. The Advocate General pointed out that the mass of evidence heard supported the native evidence, regardless of confusion over dates and times. When Perria provided the 'native names' for localities, defence implied the interpreter was making false statements. Perria gave the same answer to several different questions. Asked to point out Jones and Morris, 10-year-old Perria hesitatingly pointed out the wrong man to 'a volley of hisses, accompanied by a stamping of the feet' (the 'conduct of the people in the body of the court was indecorous and improper'). ${ }^{92}$ Sensing young Perria's bewilderment, the Advocate General submitted Melaityappa's deposition, which Mann refused to admit. Throughout, the Advocate General stood firm and 'acquitted himself admirably' despite being addressed by 'many severe, and some not civil observations'. ${ }^{93}$ Mann concluded the case by saying the evidence was not sufficient and the 'only safe course of the Jury ... [was] to acquit the prisoners'. 'Without hesitation' the jury returned a verdict of not guilty:

88 GRG 5/2/1849/406, SRSA.

89 Advocate General to Colonial Secretary, 5 January 1845, GRG 24/6/1845/143, SRSA.

90 Register, 19 September 1849: 3E, emphasis added.

91 Register, 19 September 1849: 3E.

92 Register, 19 September 1849: 4A.

93 Register, 19 September 1849: 4A. 
On the liberation of the prisoners, the silence which had been rigidly preserved in the court during the late proceedings ... gave way to a tumultuous expression of satisfaction. The long pent up feelings of the audience found vent in a mighty volley of cheers, which completely put the efforts of the officers of the Court at defiance. The cheers were repeated outside the Court, and the traders of Hindley street were startled occasionally by a sudden but simultaneous shout from a large body of people, who had not separated even at that distance from the Court-house. ${ }^{94}$

In the court and on the streets, Adelaideans celebrated the failure of British law to convict the murderers of an innocent Aboriginal man.

The jury's verdict appears popular. The editors of the $S A G M J$ no doubt represented the relief and thinking of many:

we have not the least intention of treating this matter with levity - far from it. A cruel and brutal murder had unquestionably been perpetrated upon a native, which, brought home to the accused parties, would certainly have been expiated with their lives. Fortunately, this dire justice has been avoided; and more happily still, the determination which the proceedings evinced is likely to operate as a warning to others in their future intercourse with and treatment of the aborigines, and so have the full effect of a more terrible example. ${ }^{95}$

Some colonists were disappointed; on 18 September, 'H.W.' wrote that the 'result of the last trial has given much dissatisfaction to many worthy individuals in the province, who regret, with myself, the want of proper interpreters' ${ }^{96}$ But many were satisfied; a memorial dated 17 September 1849, 'signed by a great number of leading colonists', requested that 'her Majesty, in answer to the wishes of her faithful and loyal subjects in South Australia, will be graciously pleased to appoint Chas. Mann, Esq. [to the office of second Judge]' ${ }^{97}$ Clearly, Mann had proven his ability to make the administration of justice palatable to many.

\section{Reverberations}

During the same Criminal Sittings, four Eyre Peninsula Aboriginal men were found guilty for the murder of Beevor and Easton. As with Jones and Morris, the case for the defence rested upon Aboriginal evidence. This was a prime opportunity for Mann and the jury to demonstrate the alleged impartiality of British law. However, the jury had no problems convicting Aboriginal people on the basis of Aboriginal evidence. In the same sittings, no European was found guilty for the murder of 
Nantariltarra or the death of the girl who drowned. The inconsistency of the judgments was not lost on Moorhouse and other high-placed officials who lost faith in the British judicial system's impartiality and effectiveness.

In a letter to the Governor dated 8 October 1849, Moorhouse asked the Governor to reconsider the sentence of death pronounced upon the four Aboriginal men from Eyre Peninsula. Moorhouse felt obliged to:

conscientiously declare my conviction, that had they been Europeans, the juries would not from the evidence produced have brought them in guilty ... the chief evidence against them was given by Natives, a kind of evidence which a few days before had been rejected as dangerous and unsatisfactory when given against Europeans. ${ }^{98}$

The Governor also received a memorial headed by the Bishop of Adelaide and signed by 32 prominent and respected colonists asking for a respite or commutation of the death sentence for the four Aboriginal men. The memorialists were concerned about the 'recklessness likely to be fostered with regard to treatment of the native population, if the machinery of the Law is found ineffectual to reach the White offender, but acts with unmitigated severity upon the Black'. ${ }^{99}$

Moorhouse's letter and the memorial were forwarded to Mann for review. (Nettelbeck and Foster state 'Judge Mann took the unusual step of writing to the Governor with concerns about the case'. ${ }^{100}$ In fact, Mann was compelled to provide a response.) Both Moorhouse and the memorialists made it very clear that rather than being the original aggressors (as Mann informed the jury), Aboriginal people were retaliating for 'numerous and undoubted outrages involving adulterous abstraction of the Native women and homicide of the Natives upon the part of whites'. ${ }^{101}$ Mann, however, distinguished between Aboriginal crimes, which he described as 'preconcerted' and demonstrating 'unity of design', and European crimes ('acts of individuals'). Mann stated this despite having been informed of the premeditated attack by five Europeans on the shores of Hardwick Bay in which Nantariltarra was murdered and a girl drowned, and despite knowing of the poisoning of at least five people on Eyre Peninsula. Mann claimed 'the natives and the white population are dealt with impartially'. Although 'morally speaking' there could be 'little doubt' of 'the means by which and the parties by whose hands' Melaityappa met his fate, 'the jury were indifferently directed to acquit the prisoners' because the native testimony 'was too uncertain to warrant a conviction'. ${ }^{102}$

98 Moorhouse to Colonial Secretary, 8 October 1849, GRG 24/6/1849/1850, SRSA.

99 Memorial to the Governor, received 8 October 1849, GRG 24/6/1849/1847, SRSA.

100 Nettelbeck and Foster 2010: 333.

101 GRG 24/6/1849/1847, SRSA.

102 Mann to Colonial Secretary, 10 October 1849, GRG 24/6/1849/1893, SRSA. 
Referring to the bias of the court system, Moorhouse stated:

A most disadvantageous position in which Natives are placed appears in the prejudicial feeling existing in the minds of juries - This prejudice was forcibly displayed in the minds of jurors during the late [September] trials ... The poor Natives meet with little sympathy or compassion before tribunals composed entirely of white men. ${ }^{103}$

The memorialists similarly referred to 'the wide-spread prejudice, unconsciously perhaps, affecting the value of the defence'. ${ }^{104}$ In response, Mann obliquely stated this complaint did not 'amount to objections in limine' but 'merely' 'suggest an imperfection in the machinery of trial'. ${ }^{105}$ Contrary to the memorialists, Mann believed his judgments demonstrated the sanctity of British law and would maintain settler respect for the law and, consequently, limit settler violence.

The fact that Mann was ordered to report on the outcome of the trials of Jones and Morris and the Eyre Peninsula men and to respond to Moorhouse's and the Memorialists' letters shows the Governor had concerns regarding Mann's judgments. Having received Mann's response, the Governor recommended Mann 'state explicitly in an addendum to his report that the convictions were obtained (as his report implies) in due course of Law. ${ }^{106}$ Moorhouse had stated in his appeal that if 'His Excellency and the Executive Council' did not show leniency and mercy to the four condemned men, he should 'have some difficulty in believing the declaration that the Natives enjoy the protection of the British Law' ${ }^{107}$ All relevant documents were laid before the Legislative Council on 24 October. Apparently finding Mann's argument more palatable but recognising some gesture of compromise was required, the Council 'resolved unanimously that the Lt Governor should not be advised to pardon or reprieve' two of the four Aboriginal men. ${ }^{108}$

\section{Conclusion}

The circumstances surrounding the trial of Jones and Morris were unique. The trial provided an unprecedented opportunity to demonstrate to South Australian colonists the much-promulgated notion that Aboriginal people were treated as equals before the law. However, despite the strength of the case against Jones and Morris, and regardless of the determined and decisive actions of government officials, the opportunity for the judiciary to show leadership (which may have altered the extent and degree of settler-Aboriginal violence in newly occupied and

103 GRG 5/2/1849/406, SRSA.

104 GRG 24/6/1849/1847, SRSA.

105 GRG 24/6/1849/1893, SRSA.

106 Governor Young to Master of Supreme Court, 9 October 1849, GRG 24/6/1849/1852, SRSA.

107 GRG 24/6/1849/1850, SRSA.

108 W. O’Halloran, Clerk of Council, 24 October 1849, GRG 24/6/1849/1852, SRSA. 
remote districts) was lost. In 'making the administration of justice palatable' to the settlers, Judge Mann's dubious actions and judgments show the extent to which landholding settlers constituted and controlled the law and how, at the highest court in the colony, the short-term economic interests of a particular group of settlers and the economic 'locomotion' of the province took priority over the lives of the original owners of the soil. ${ }^{109}$

\section{References}

\section{Archival Sources}

\section{State Records of South Australia [SRSA]}

Colonial Office Correspondence (incoming), Government Record Group [GRG] $24 / 6$

Police Correspondence, GRG 5/2

Supreme Court Letter Books, NNB 27 [Government Record Series [GRS] 13038/1/P/Vol. 6]

Surveyor General's Office GRG 35/1849

\section{Newspapers}

South Australian Gazette and Mining Journal [SAGM]

The Adelaide Observer

The Adelaide Times

The South Australian Register [Register]

\section{Published sources}

Brock, Peggy and Doreen Kartinyeri 1989, The Rise and Destruction of an Aboriginal Agricultural Community, South Australian Government Printer and Aboriginal Heritage Branch, Adelaide.

Broome, Richard 2003, 'The statistics of frontier conflict', In Frontier Conflict: The Australian Experience, Bain Attwood and S.G. Foster (eds), National Museum of Australia, Canberra: 88-98. 
Davies, Susanne 1987, 'Aborigines, murder and the Criminal Law in early Port Phillip 1841-1851', Historical Studies 22(88): 313-35. doi.org/ $10.1080 / 10314618708595754$.

Ford, Lisa 2010, Settler Sovereignty: Jurisdiction and Indigenous People in America and Australia, Harvard University Press, Cambridge, MA.

Foster, Robert 1998, 'The legend of James Brown', Australian Historical Studies 29(11): 210-29. doi.org/10.1080/10314619808596070.

Foster, Robert, Rick Hosking and Amanda Nettelbeck 2001, Fatal Collisions: The South Australian Frontier and the Violence of its Memory, Wakefield Press, Adelaide.

Foster, Robert and Amanda Nettelbeck 2012, Out of the Silence: The History and Memory of South Australia's Frontier Wars, Wakefield Press, Adelaide.

Kercher, Bruce 1995, An Unruly Child: A History of Law in Australia, Allen \& Unwin, Sydney.

Krichauff, Skye 2011, Nharrungga Wargunni Bugi-buggillu: A Journey Through Narungga History, Wakefield Press, Adelaide.

_ 2015, 'Native Police Constable Jim Crack: The establishment of peaceful relations between Narungga, pastoralists and "wild white men" on Yorke Peninsula’, Journal of Australian Indigenous Issues 18(1): 7-23.

Lester, Alan 2002, 'British settler discourse and the circuits of empire', History Workshop Journal 54(1): 24-48. doi.org/10.1093/hwj/54.1.24.

Levinson, James 1993, 'The trial of Thomas Donelly', Journal of the Anthropological Society of South Australia 31(2): 54-66.

Nettelbeck, Amanda 2013, “Equals of the white man": Prosecution of settlers for violence against Aboriginal subjects of the Crown, colonial Western Australia', Law and History Review 31(2): 355-90. doi.org/10.1017/S0738248013000060.

Nettelbeck, Amanda and Robert Foster 2010, 'Colonial judiciaries, Aboriginal protection and South Australia's policy of punishing "with exemplary severity", Australian Historical Studies 41(3): 319-36. doi.org/10.1080/1031461X. 2010.493947.

Patton, Barry 2006, 'Unequal justice: Colonial law and the shooting of Jim Crow', Provenance: The Journal of the Public Record Office Victoria 5: 1-13.

Pope, Alan 1998, 'Aborigines and the Criminal Law in South Australia: The first 25 years', unpublished $\mathrm{PhD}$ thesis, University of Adelaide. 
_2011, One Law for All, Aboriginal Studies Press, Canberra.

Salter, Brent 2008, "For want of evidence": Initial impressions of Indigenous exchanges with the first colonial Superior Courts of Australia', The University of Tasmania Law Review 27(2): 145-60.

Smandych, Russell 2004, 'Contemplating the testimony of “others": James Stephen, the Colonial Office, and the fate of Australian Aboriginal Evidence Acts, circa 1839-1849', Australian Journal of Legal History 8(2): 237-84. 
This text is taken from Aboriginal History, Volume 41, 2017, edited by Ingereth Macfarlane, published 2017 by ANU Press, The Australian National University, Canberra, Australia.

dx.doi.org/10.22459/AH.41.2017.02 